\title{
Mitigation measures for preventing soil erosion that adversely affects horticultural products
}

\section{Introduction}

The Webster College Dictionary defines horticulture as "the science or art of cultivating flowers, fruits and vegetables". Horticulture includes gardening, which is the practice of growing and cultivating plants. Useful plants, such as root vegetables, leaf vegetables, fruits, and herbs, are grown for consumption.

Gardening may be very specialized, with a given type of plant grown, or involve many different plants in mixed plantings. It involves an active participation in the growing of plants, and tends to be laborintensive, which differentiates it from farming or forestry. Steady water supply, without interruption is a must for plants. Irrigation and horticulture have been in practice since centuries. Advantages of horticulture being the area looks beautiful, it reduces pollution, green trees improve health and minimize diseases. Water quenches thirst but excess water can destroy the crop. Although much of the world's surface is water, it is not fit for domestic use and water needs to be treated by desalination plants. Growing of grains may require large fields but growing vegetables, fruits and flowers in the backyard does not require large areas. Irrigation is one of the applications of hydrology while soil science relates to geotechnical engineering. Water is the daily need of human beings besides that of animals and plants, while both human beings and animals rely mainly on plants. Plants utilize water supply from rivers and rain. Both surface water and underground water table and fertile soil are required. Especially, in third world countries with large populations, food supply is a daily problem. Without abundant supply of grains such as rice, wheat and pulses famines may result. Vegetables and fruits supplement them as regular part of meals.

In this paper, 21 st century solution to century-old problem of soil preservation is presented. The resulting cost impacts of constructing the engineering infrastructure, for providing a steady water supply to the gardens and fields, in planning, planting and harvesting, are emphasized. The key distinction between gardening and farming is essentially one of scale; gardening can be a hobby or an income supplement, but farming is generally understood as a full-time or commercial activity, usually involving more land and quite different practices. One distinction is that gardening is labor-intensive and employs very little infrastructural capital, sometimes no more than a few tools, e.g. a spade, hoe, basket and watering can. By contrast, larger-scale farming often involves irrigation systems, chemical fertilizers and harvesters or at least ladders, e.g. to reach up into fruit trees.

A botanical garden is a garden dedicated to collection, cultivation and display of a wide range of plants labelled with their botanical names. Birds travel from long distances when they spot green trees and forests.

\section{Essential natural elements for growing plants}

The 3 primary elements for irrigation are the type of soil, water supply and regular sunlight. Secondary elements are fertilizers and compost.
Volume 2 Issue 6 - 2018

\author{
Mohiuddin Ali Khan \\ Consulting Engineer and Adjunct Professor, Associates and \\ Temple University, USA \\ Correspondence: Mohiuddin Ali Khan, Consulting Engineer \\ and Adjunct Professor, Associates and Temple University, \\ Philadelphia, PA, 606 McElwee Road, Moorestown, New Jersey \\ 08057, USA, Tel 8562731855, Email Mohedin@temple.edu
}

Received: May 14, 2018 | Published: November 16, 2018

\section{Extreme environmental elements}

Both the quality and quantity of agricultural produce are adversely affected by the following extraordinary and natural events:

1. Recurring Floods

2. Heavy rains and monsoons

3. High and low temperatures, snow fall

4. Tornados

5. Earthquakes and Tsunamis

6. Land slides

7. Wild fires

8. Volcanos.

Examples of each event are prevalent all over USA. Horticulture is delicate, easily affected and the economic loss is incalculable.

\section{Frequent floods due to tornados, snow melt and heavy rains}

Floods are extraordinary events happening usually once every 100 years and 50 years respectively. Most of the extreme events cause soil erosion. Soil erosion remains a leading result of floods and is known as scour. Scour is defined as "the erosion or removal of streambed or bank material due to the flowing water from fields and gardens". In USA, some examples of floods from rivers caused by hurricanes are given as follows:

It has been nearly ten years ago that Hurricane Katrina devastated the US Gulf Coast.

i. Hurricane RITA struck in 2005 ,

ii. Hurricane IKE in 2008,

iii. The Midwest floods in 2011.

iv. In New Jersey for example, there are examples of Hurricane Floyd in 1997 and

v. Hurricane Sandy in 2011. It led to over 2000 lives and loss of billions of dollars to crops, commerce and damages to property. The massive effort for flood risk management involves the following: 
vi. After 2005 Hurricane Katrina disaster, US Army Corps of Engineers set up a Task Force, "Interagency Performance Evaluation Task Force" (IPET) to conduct an inquiry into the failure of the important New Orleans Hurricane Protection System.

At the request of US Army Corps of Engineers, ASCE External Review Panel prepared a report, which came up with advantages of introducing flood risk management and following main recommendations:

i. Mitigating the consequences of flooding including horticulture,

ii. Taking structural and nonstructural measures for a resilient infrastructure,

iii. Assessing risks,

iv. Effective and sustainable management of risks to life, health, horticulture, economic activity, cultural heritage and environment.

v. Risk sharing by all stake holders

vi. Funding allocation on a priority basis.

vii. Making emergency preparations in the short term

viii. Strengthening the flood protection systems for the long term, by coming up with the required minimum funding.

\section{Cumulative risks}

A high level of initial risk faced by a community can be mitigated by cumulative risks as:
i. Zoning
ii. Natural storage
iii. Levees and floodwalls
iv. Damage to plants avoided by early harvesting and
v. Drainage and evacuation plans if required.

\section{Environmental policy}

Environmental impacts cause scour and stream instability. Standard countermeasures need to be provided. Their selection, design and installation criteria is to emphasize environmental enhancement and sustainability. The approach should be with creating minimum risk to lives and property, in applying environmental policy to structures in a riverine system.

\section{Watering requirement}

A good general guideline is an inch of water per week, either by rain or watering; in arid climates.

It is double that in hot weather Vegetables need even more water, up to about $1 / 2$ inch per week extra for every 10 degrees that the average temperature is above 60 degrees. That needs to be adjusted in hot weather for squash, eggplant, tomatoes, and other crops that need lots of water and have big leaves that may wilt easily. Farming experience over a number of years is desirable. Many farmers have expertise in the agricultural applications usually acquired from earlier generations.
Floods are an act of god like the creation of the rest of universe

Impacts of environment and natural elements cannot be ignored. Old Indian concepts of the four natural elements are always applicable, namely "water, fire, wind and earth are Gods unto themselves".

\section{i. Fury of major floods}

ii. Impact of small floods can also be detrimental.

iii. Collapse, near failure, damage or potential damage is all undesirable.

Failures are like open books. They serve as pillars of success.

The experience gained from failure analysis can be applied to develop existing planting methods, and in developing a code of practice. Failure mechanism and a lot more can be learnt from studying the reasons of failure. Through failure case studies of water distribution system during floods, we learn the technical issues, the causes, and modes of failure of various structures.

\section{Erosion and US forest service bridge scour evaluation}

Scour is the single most common cause for structural damage and produce failure on National Forest lands. In 1998, the Forest Service Engineering Technology Development Center developed a scour evaluation program in response to a Federal Highway Administration Technical Advisory to require evaluation of all bridges for susceptibility to damage resulting from scour.

Bridges over rivers should be functional during floods there are many techniques of controlling erosion at bridge sites, which result from obstruction to water flow and neighboring fields have increased flood level. Flood diversion methods can be successful in controlling water in irrigation fields. They are,

i. River training measures to slow down flood velocity,

ii. Monitoring and flood watch to take immediate action such as detour and shutdown,

iii. Plantation to stabilize the sides of banks etc.

iv. Resisting the type of erosion (Aggradation and Degradation)

v. Lateral channel instability during floods leading to meander and change in the direction of flow.

vi. Vertical channel instability results in breach of levees near bridges and overtopping.

\section{River contamination and encroachment}

It will result from the foreign materials adversely affecting ecology such as marine life, habitats and plant life.

\section{Frequent floods in USA}

Major rivers like Ohio and Mississippi have recurring floods. Both Northern and Southern California were subjected to heavy rain and floods along the Pacific Coast. Major floods occurred in 1938 and 1958. The floods were followed by landslides resulting in casualties and road closures. It required hundreds of miles length of tall retaining walls to be constructed, to protect the highways and horticulture costing billions of dollars. The drainage of the cliffs during and after 
the rains was introduced by a network of pvc pipes. Many nearby towns lying at lower elevations than overflowing banks are inundated with flood water, causing loss of property and life.

\section{Kentucky}

Two floods in particular over the past few years have raised alarm among residents, one in July 2010, the other in July 2013. Both inundated hundreds of homes in the basin around I-75 in Northern Kentucky known as the Willow Run Creek watershed. Flooding problems in some areas of Covington have lingered for decades. Midwest: There are recurring examples of floods in the Midwest. Due to torrential rains in April and May 2011 there were record flash floods. In the Mississippi River, the damage to property from water overflowing the banks was very high, compared to the 1927 record floods. Similarly, the fast-flowing Ohio River is subjected to floods and bridges need to be shut down.

\section{Minnesota}

Following fatal collapse of an Interstate bridge in Minnesota some years ago, the spotlight was thrown on the poor condition of many major structures. The ensuing investigations showed many bridges in the US to be functionally obsolete or structurally deficient.

\section{North Jersey}

Snow melt combined with heavy rain can cause floods. Hurricane Floyd turned Interstate Route 46 into lakes causing travel disruption.

Oklahoma: Oklahoma was hit again on June 2nd, 2013, this time with flash floods. Eight people lost their lives and many houses collapsed. This was like adding insults to injuries, following the wrath of nature due to tornadoes that hit only a few weeks earlier.

\section{Rhode Island}

The Narragansett Bay Commission is building a key part of a system of pipelines and tunnels to contain contaminated storm water that inundates Providence's century-old sewer system during rains. But when enough rain falls in a short period of time, the system becomes overtaxed and dirty water spills into the upper reaches of the Bay before it can be cleaned up. Storm water is being cleaned in phases.

\section{Texas}

Another example of flood is the record rise in river level in and in the Southern States. St. Antonio Texas on May 25th in which a woman drowned.

\section{Washington State}

The most recent May 23rd, 2013 when thousands of dry streams and rivers are subjected to both seasonal and out of season flood (Figure 1).

\section{China}

Flood hazards are a global problem: Floods occur across the globe, where ever there are fast flowing rivers. Examples of major floods in some of the flood devastated countries are presented below. Adverse effects of floods are felt not just in the US. In August 2010 China had major floods: China had two separate floods which killed as many as 1500 people.

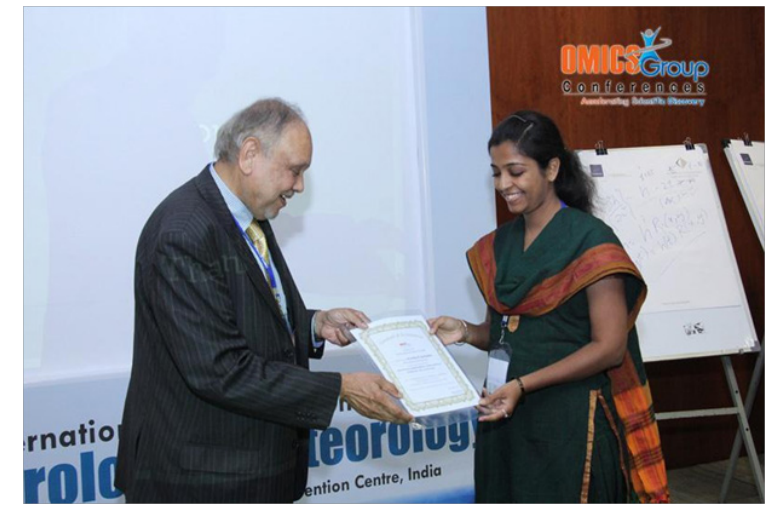

Figure 1 The author presenting an award to a lady professor in Hyderabad, India, who presented a research paper related to horticulture in OMICS Conference.

\section{Indian subcontinent horticulture}

Snow melts from the tallest mountain range (the Himalayas) are responsible for major floods in rivers like the Indus and Ganges etc. Both the volume and variety of horticultural produces in the subcontinent are however phenomenal. The area now boasts of 1.5 billion population and of their daily food supply. There are local names of flowers, vegetables and fruits in local languages. A comprehensive dictionary of technical and non-technical terms is needed. Some tropical flowers have scents stronger than perfumes and may attract snakes as a result. Butterflies and honey bees are bye-products of agriculture. It is a subject for students of botany for research in the important subject. Worms, shining glow flies, velvet leaves and thorns have been the subject of poetry. There are any number of recipes for vegetables, due to large variety of plants and perfected by ancient civilization.

\section{Bangladesh}

Each year in Bangladesh about 26,000 km2, (around 18\%) of the country is flooded, killing over thousands of people and destroying millions of homes! The floods have caused devastation in Bangladesh throughout history, especially during the years 1966, 1987, 1988 and 1998. The 2007 South Asian floods also affected a large portion of Bangladesh. Recent floods occurred in 2010.

\section{Pakistan}

July 2010 Floods the heavy monsoon rains caused floods in Northwest Pakistan. Nearly, 2000 people lost their lives and flood water destroyed agricultural crop. Jacobabad received the heaviest Monsoon downpour of over 12 inches. Recurring floods occur every year from overflow of the Indus River. Flash floods triggered by heavy rains caused widespread destruction across vast swathes of the country, breaking a 24-year rainfall record namely: Violent currents of 145,000 cusecs in Wadoor, 82,000 cusecs in Shoori Lund and 22,000 Cusecs in the torrents breached the under-construction Kachhi Canal and the DG Khan Canal. About 10,000 houses were affected and 75,000 people displaced in the district. The engineering wing of the army was plugging the canal breaches. Meanwhile, rain kept lashing other towns of central and south Punjab. The Suleman Range hill torrents caused havoc in Dera Ghazi Khan and districts of Punjab. At least five districts of eastern Baluchistan were cut off from the rest of 
the country after floodwater submerged railway tracks and highways in Nasirabad and Jaffarabad.

\section{India}

In June 2013, flash floods and landslides in northern India killed at least 1,000 people in the Himalayan state of Uttar Akhand with thousands missing or stranded toll was expected to rise. Arizona and Texas have similar climatic conditions. They have wide rivers like Ganges, Tapki and Godavari. Novel methods of irrigation can be observed in some South American and African countries due to large rivers.

\section{Soil types}

To determine grain size distribution for a scour analysis, samples from river bed need to be tested in accordance with ASTM D422 for stability. Soils are generally made more fertile by composts, like manure (animal waste).

Fertile soil types may be broadly classified as:

\section{Non-cohesive materials}

The threshold of movement depends on Particle size, Density, Shape, Packing and Orientation of bed material,

for example, gravels, sands and silts

\section{Cohesive materials}

Most fine-grained sediments possess some cohesion. The clay content is of great importance.

Cohesive sediments typically require relatively large forces to detach the particles and initiate movement, but relatively small forces to transport the particles away. Cohesive materials are silts and clays (Table 1). The roots of plants can easily get dislodged from the soil when rate of scour is higher. Cottage gardens were originally created by the workers that lived in the cottages, to provide them with food and herbs, with flowers planted among them for decoration. Farm workers were provided with cottages that had architectural quality set in a small garden - about an acre-where they could grow food and keep pigs and chickens.

Table I Geotechnical Factors and soil types in prediction of scour

\begin{tabular}{llll}
\hline $\begin{array}{l}\text { Observed } \\
\text { scour in rivers }\end{array}$ & $\begin{array}{l}\text { Typical duration } \\
\text { of maximum } \\
\text { scour depth }\end{array}$ & Sediment type & $\begin{array}{l}\text { Percentage } \\
\text { scour }\end{array}$ \\
\hline Sand & In hours & Sand & 48 \\
Cohesive & In days & $\begin{array}{l}\text { Cohesive } \\
\text { Materials }\end{array}$ & 19 \\
Materials & In hours & Mixed Soil & 13 \\
Mixed Soil & In hours & Gravel & 10 \\
Gravel bed & & & \\
\hline
\end{tabular}

Gardening also takes place in non-residential green areas, such as parks, public or semi-public gardens (botanical gardens) amusement parks, along transportation corridors, and around tourist attractions.

Indoor gardening: It is concerned with the growing of houseplants within a residence or building, in a conservatory, or in a greenhouse.

Indoor gardens are sometimes incorporated as part of air conditioning or heating systems. Indoor gardening extends the growing season in the fall and spring and can be used for winter gardening. a. Native plant gardening is concerned with the use of native plants with or without the intent of creating wildlife habitat. The goal is to create a garden in harmony with and adapted to a given area. This type of gardening typically reduces water usage, maintenance, and fertilization costs, while increasing native faunal interest.

b. Organic gardening uses natural, sustainable methods, fertilizers and pesticides to grow non-genetically modified crops.

The production of ornamental plantings around buildings is called landscaping, landscape maintenance or grounds keeping, while international usage uses the term gardening for these same activities. Garden pests are generally plants, fungi, or animals (frequently insects) that engage in activity that the gardener considers undesirable. Snails may be dealt with through use of chemical pesticide, an organic pesticide, hand-picking, barriers, or simply growing snail-resistant plants. Plants are delicate and need to be looked after daily. The gardener needs to spend one or two hours daily for ensuring adequate water supply, compost and taking care of pests (Figure 2).

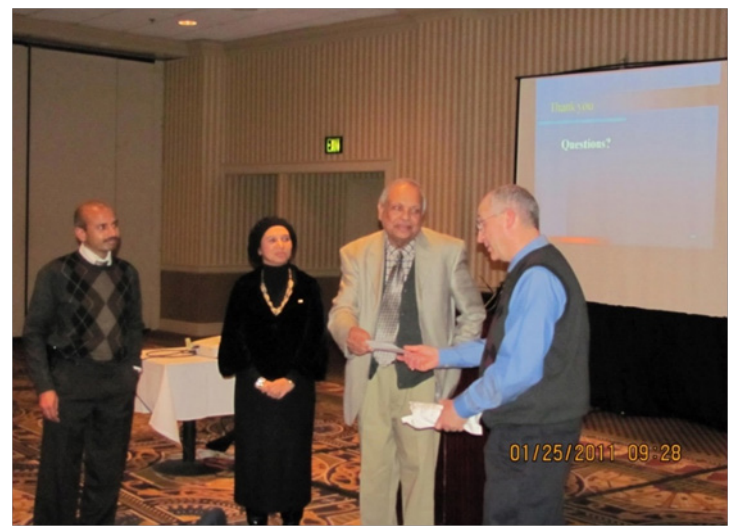

Figure 2 The author presenting a certificate of appreciation on behalf of Structural Eng. Institute, Philadelphia to Head of SEI National.

\section{Mitigation measures}

1. Civil engineering structures are needed to distribute and contain flood water. These include dams, barrages, tunnels, culverts and earthen embankments. Much work needs to be done at Federal and State levels. The cost of safe infrastructure and wider canal system can run into hundreds of million dollars, but it will pay back from the recurring returns of cultivation.

2. In addition, machinery such as water pumps and sprinklers are needed. The quality of water is also maintained by desalination plants. Field drainage also needs to be provided to maintain steady water levels.

3. To avoid excess flood water from inundating the field and damaging the crops and plants, the large volume of water can be stored in dams. The water can be distributed to the tributaries of rivers through a system of canals.

4. To boost the economy of the country and for a healthy diet, every household can contribute by growing fruits (such as planting fruit trees for apples, oranges, guava, berries, coconuts, mangos, lemons etc). Domestic vegetable plants for tomatoes, beans, cauliflower, carrots, corn, onions, peppers, mint and avacardo etc.) are very useful to produce. A salad dish is most popular due to its taste. The daily efforts also serve as a pastime. 
5. Technology transfer in horticultural and agricultural sectors: From countries with advanced technology in horticulture advice can be gained based on their experience. Emergence of farm markets and their low affordable prices are good for public health and healthy diets. No amount of manmade industries can replace or compete with abundance in natural horticulture. Farm markets can be rightly regarded as "Heavens on Earth" and are sources of life both for the rich and poor.

6. Small parks to be provided if possible at every street. The local authority needs to acquire lots and purchase them for public recreation and enjoyment. Ponds with fishes will be an added attraction. When trees grow to their full height in say twenty years, they will provide shade in the blazing red-hot sun.

7. Local centers can be set up to educate and advise people on farming methods. For example, a $3 \mathrm{ft}$. strip inside the boundary wall can be reserved for plants and vegetables. Regular conferences and seminars can be held by these promotional centers. The nutritional and medical advantages can be emphasized.

8. Free potting soil can be provided as encouragement. In addition to seeds, hoses and pipes may be provided at a low price to promote.

9. Flower and vegetable competitions can be held each month and prizes be awarded. Peace of mind is achieved to see the plants grow, yield fresh produce and the flowers bloom

\section{Conclusion}

1. With so much advent in modern day technology like internet voluntary support and cell phones, people have converted to "life-long learners". Local libraries can help with the lending of books on various aspects of horticulture, holding seminars and are great sources of information. Domestic and gardening in back yards of houses will have far reaching benefits.

2. People in apartments can use pots and place them in their windows and sitting rooms. It adds to decoration and keeps the air relatively clean by containing the traffic fumes from streets.

3. The botany, names of plants and their variety is different for all types of vegetables, fruits and flowers in tropical countries like India. An effort should be made to import them in Europe and North America for trans-plantation and making them popular. The roots of mankind emanate from ancient jungles. Green has an affinity for color.

4. Besides horticulture being a hobby, there are economic benefits. Recurring plants are like opening a bank account. Monsoon rain can be collected in buckets for use and stored in small ponds. The survival of huge and growing population in third world countries is due to horticulture use in their small backyards, dependence on which they are proud.

5. Major earthquakes (like of magnitude 7.6 which struck Pakistan in 2005) can cause disruption of water supply for irrigation purposes. It therefore takes a long time to recover. Flexible pipe joints may be considered.

6. Surplus and bumper crops can be distributed to friends and people with low incomes.

7. Small investment by administration is not excessive. The motto should be "to grow more trees". The leaves and branches can serve as food for lambs and sheep. Prizes should be awarded to the winners. The aim should be to leave the world in a better shape than originally found by the individual. There are century old sayings that "where there is a will, there is a way" and "a journey of a thousand miles starts but with a single step (Figure 3) (Figure 4).
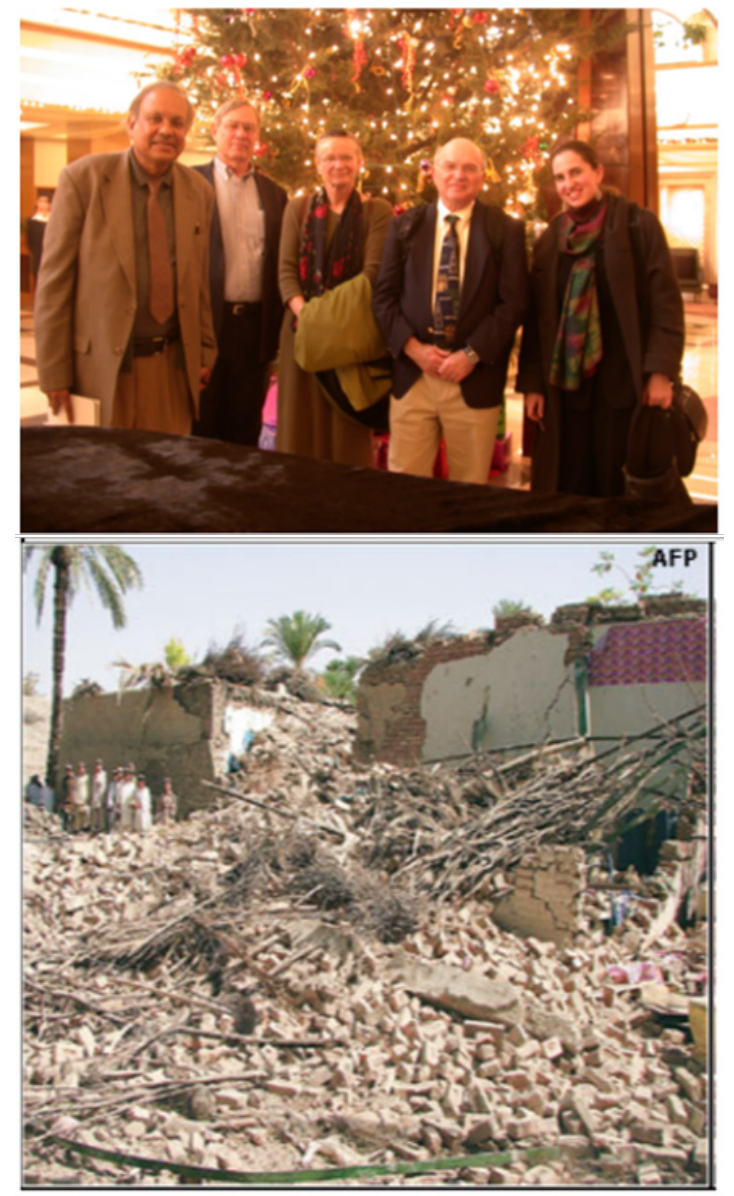

Figure 3 US AID Team visiting North Pakistan, after October 2005, earthquake. The author is on the left. (Towns and plants destroyed).

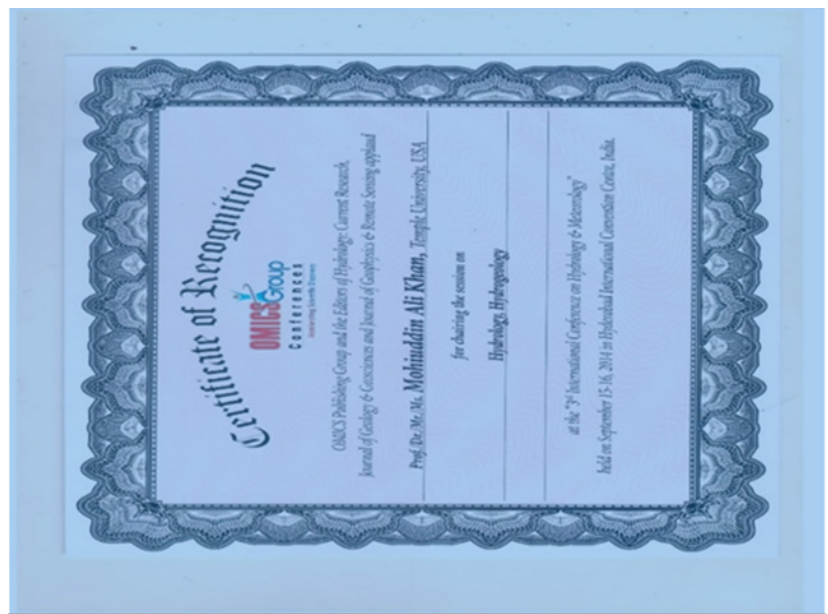

Figure 4 Tropical climate affecting local horticulture issues discussed at Conference. 


\section{Acknowledgements}

None.

\section{Conflict of interest}

Author declares that there is no conflict of interest. 